\title{
How Welfare-State Regimes Shape Subjective Well-Being across Europe
}

\author{
Robin Samuel \& Andreas Hadjar
}

This is a post-peer-review, pre-copyedit version of an article published in Social Indicators Research (2016), 129:565-587.

The final authenticated version is available online at:

http://dx.doi.org/10.1007/s11205-015-1125-0

Note that in the published version, an error was introduced in table footnote $1 \mathrm{~b}$ (classification of countries into welfare-state regime types). The document you are reading contains the correct information.

\begin{abstract}
Welfare-state regimes achieve different outcomes in dealing with social inequalities. For example, the social democratic or Scandinavian welfare-state regime is often considered as the most egalitarian with a high social transfer rate and a comparably low level of income inequality. While most research on welfare-state regimes focuses on objective indicators of quality of life and inequalities, we are interested in how citizens actually evaluate their lives, using subjective well-being (SWB) as an indicator. The paper deals with two research questions: (1) How does the welfare-state regime affect subjective well-being, and (2) does the welfare-state regime influence the effect of status on SWB? Status is an essential firstorder goal to produce subjective well-being according to the social production theory of Lindenberg and colleagues (Ormel et al. 1999), but is also linked to many other instrumental goals such as comfort and stimulation. The study carries out a multilevel analysis using pooled European Social Survey data from the years 2002-2012, covering more than 30 European countries. While we first look at how status drives SWB levels in different welfarestate regimes as classified by (Esping-Andersen 1990, 1999), our focus is mainly on crosslevel interactions between welfare-state regime type and the relationship between status and SWB. Our results provide evidence that social-democratic welfare-state regimes not only provide for living standards that are associated with the highest SWB levels, but also compensate best for status differences in SWB compared to other welfare-state regimes.
\end{abstract}

\section{Keywords}

Welfare-state regimes - Status - Subjective well-being - Social production function theory · Social inequality $\cdot$ Multilevel analysis 


\section{Introduction}

The level of subjective well-being (SWB) in a country is a major indicator of its quality of life and 'liveability' (Veenhoven 2001). What kind of society provides the best living conditions is a longstanding research question. According to decades of quality of life research and studies on SWB (Diener and Suh 1997; Diener 2009), a 'good society'1 or 'liveable society' may be considered one that ensures high living conditions and, at the same time, minimizes the link between individual level conditions, such as status, and SWB by compensating for certain disadvantages, such as income inequalities that may be associated with lower SWB. However societies differ in the way they set about enabling a good life for all citizens. This is exemplified by the various welfare-state regimes present in different countries. Looking at research to date quickly reveals profound country differences in SWB and the effects of individual level determinants on SWB (Böhnke 2008; Bonini 2008; Pedersen and Schmidt 2009). Major factors for divergence in SWB between various welfare-state models are "economic performance, the social security level, and the political culture in a country—all in all, general conditions that enable people to live a respectable life” (Böhnke 2008, p. 189). From a social inequality perspective the question is how the welfare-state regime, as a macro characteristic, shapes SWB. On the individual level, the question is how markers of inequality, such as status, predict SWB, and how these are shaped by macro characteristics. Welfare-state regimes not only impact objective inequalities and quality of life, but also how individuals subjectively perceive inequality with clear consequences for their subjective wellbeing. Thus, in this paper we will explore how welfare-state regimes impact a) the societal SWB level and b) the relationship between status and SWB link on the individual level.

Our study makes several original contributions to the field of social indicators research. Empirical studies comparing different societies from a social inequality perspective has focused to date primarily on the distribution of goods and positions as well as whether a

\footnotetext{
$1 \quad$ We are interested in the subjective well-being of people on the individual and macro level. In this sense, we study what people might evaluate to be a good and liveable society, leaving the question aside of what a good society constitutes or whether it is at all possible to define a good society.
} 
society succeeds in mitigating differences in the acquisition of status, income, prestige or education (Treiman and Ganzeboom 2000), while neglecting the individual-level perceptions of inequality. According to Thomas and Thomas (1928), the subjective perception of a situation is even more important for behavior and, in particular, decision-making, than objective characteristics. More recently, Veenhoven (2005, p. 352) claims that happiness measured as the subjective perception of living conditions is "possibly a better indicator than the income disparities that are central to comparative inequality research.” Furthermore, our study aims to contribute to scientific debate on the impact of social inequalities on SWB or happiness. While an established body of literature in social research stresses that inequality harms societies and, in particular, how living standards affect the perceived quality of individual lives (Stiglitz 2012; Wilkinson and Pickett 2010), others oppose these views (Snowdon 2010; cf. Zagorski et al. 2014). Some studies in fact that take into account economic prosperity (GDP indicators) find no effect of income inequality on SWB (Kelley and Evans 2012; Zagorski et al. 2014) and indeed find even a slightly positive correlation between income inequality and SWB after controlling for GDP (Berg and Veenhoven 2010).

This study will first describe how status and SWB are linked, drawing to this end mainly on social production theory, which includes status as a first-order instrumental goal in the production of well-being. Our hypothesis is that status and SWB are positively associated. Secondly, we develop an explanation with regard to how the welfare-state regime model affects SWB. Our key argument is that because welfare-state regimes differ in how they redistribute goods and resources, they also fare differently in their ability to enhance living conditions and, consequently, SWB. Moreover apart from affecting SWB on the macro level, we will further argue that the welfare-state regime will diminish status effects on SWB through their redistributive function. The empirical analysis is based on European Social Survey data with the relationship between macro and micro factors modeled as cross-level 
interactions. In the final section, we summarize and discuss our results in light of the varied debates introduced above.

\section{The Link between Status and Subjective Well-Being}

Subjective well-being (SWB) is defined in terms of 'how people evaluate their lives - both at the moment and for longer periods', which is a 'broad category of phenomena that includes people's emotional responses, domain satisfactions, and global judgments of life satisfaction' (Diener et al. 1999:277). SWB is comprised of both a cognitive and an affective component. Whereas the cognitive component is based on a (rational) consideration of past, present and future conditions, affective evaluation is based on emotions and feelings (see Diener 1994). SWB is influenced by individual level factors such as status which is a major marker of inequality in classical sociological research and encompasses such diverse factors as income, unemployment, living in a committed relationship, network of friends and relatives (social capital) as well as health (e.g. Frey and Stutzer 2005; Hadjar and Backes 2013). Furthermore, there are macro level impacts on SWB such as economic prosperity and the welfare-state regime (Bonini 2008; Böhnke 2008; Hadjar and Backes 2013).

In the first part of our analyses we focus on the micro level factor of status, which is strongly related to other important issues in social inequality research such as income and education. Social Production Function theory (Ormel et al. 1999) provides a general framework for determining well-being, and it places status prominently among the five firstorder instrumental goals (stimulation, comfort, status, behavioral confirmation and affection). To what extent the instrumental goal of status can be attained, for example through control over resources, depends on individual resources, which includes level of education, special skills and social class (Ormel et al. 1999: 67). Furthermore, status is strongly linked to other first-order goals in the production of well-being, as high status more often than not aligns with 
higher income (comfort), better opportunities to do stimulating leisure time activities or work in fulfilling jobs (stimulation), and, finally, with a larger social network (affection). For this reason status seemed a strong selection for our analysis.

The positive association between status and SWB is well-documented. Whereas a change in activities and endowments has a short-term impact on SWB, resources and their use are linked to long-term effects on SWB. Upward social mobility, for example, is assumed to produce status and, thus, higher levels of SWB (e.g. Hadjar and Samuel 2015). Conceptualizing the link between status and SWB can be based on two lines of thought with the first of these regarding the strong link between status and income. Although income gains are not always and linearly linked to a rise in SWB, empirical evidence shows that wealthier individuals report higher SWB levels (Frey and Stutzer 2002; Di Tella et al. 2003), due to income acting as a prerequisite to live a comfortable life and satisfy individual needs. The second argument relates to status as a positional good that is "either (1) scarce in some absolute or socially imposed sense or (2) subject to crowding through more extensive use” (Hirsch 1977, p. 27). A higher status provides a stronger position for social comparison (Festinger 1954), as higher-status people are more able to positively evaluate their status relative to others (e.g. Samuel et al. 2013). According to Festinger's social comparison theory (1954), individuals are able to make a positive self-evaluation, an essential prerequisite of well-being, through social comparisons with reference groups (see Hadjar and Samuel 2015). The value of status as a valuable positional good in itself is also described in sociological theories that refer to the "status maintenance motive" as a major driving force behind educational decisions and social mobility (e.g. Breen and Goldthorpe, 1997; Treiman, 1970; Stocké, 2007). The above leads to the following hypothesis:

Hypothesis I: Status is positively associated with SWB. 


\section{Welfare-State Regimes and Social Inequality}

Differences in status are clear indicators of social inequality on the individual level. Welfarestate regimes differ in how they deal with social inequality by redistributing goods, thereby enabling the social-economic environment for acceptable living standards for all citizens and mitigating status effects on subjective well-being (SWB). The decisions of the welfare-state on how to redistribute goods thus affects the ways in which individuals can satisfy their needs. This study considers two impacts of the welfare-state regime at the macro level: firstly, we consider the direct effect of the welfare-state regime on SWB, as welfare-state regimes aim to ensure that welfare is in fact perceived at the individual level. Secondly, we consider how different welfare-state models impact the extent to which status affects SWB, as welfarestate regimes are conceived to diminish relative disadvantage and social inequalities more broadly. Both arguments are strongly related, as the level of inequality is related to SWB levels in society, although, as we will return to later, there is some debate as to whether inequality diminishes or increases SWB levels.

Welfare-state regimes result from historical, political, and cultural developments. Definitions differ considerably between countries and social welfare is a key issue in political discourse, particularly with regard to the need for modern societies to be both economically competitive and socially fair. Esping-Andersen (1990, p. 37) distinguishes between different welfare-state regimes, focusing on decommodification and stratification as major pillars of social policy: decommodification refers to "the degree to which individuals, or families, can uphold a socially acceptable standard of living independently of market participation”. Thus, a common denominator of all welfare-state policies is to secure a minimum level of welfare for all citizens and welfare-state regimes differ in the ways they accomplish this task. We argue that the level of SWB indicates how successful certain welfare-state models have been in creating the conditions for decent standards of living. This is expected to be net of effects concerning income inequality, which will be related to SWB. The link between welfare-state 
regime and social inequality can be theorized with reference to Esping-Andersen's now welltraveled typologies (1990). As indicated above, stratification, the order of social relations, is the second key dimension of Esping-Andersen's theory (1990, p. 23), according to which welfare-state regimes as "systems of stratification” do not only offset social inequalities, but also create new ones, and reproduce those which already exist. The social policies of different welfare-state systems affect the distribution of incomes and the distribution of resources more broadly. Thus, the welfare-state regime contributes to the issue of whether or not the state ensures the best possible standard of life for all, independent of inequality characteristics such as social background, gender or race. The original welfare-state regime theoretical framework by Esping-Andersen (1990) received a lot of criticism as empirical studies hint at deviations, outliers, or neglected cases (cf. Schubert et al. 2008; Scruggs and Allan 2006). The main challenges to welfare-state typologies relate to the fact that they are "developed on a selection of country cases” (Ebbinghaus 2011, p. 19) and that gaps between ideal-typical and real welfare states appear in empirical analysis (Arts and Gelissen 2002). Many scholars asked if there are more (Castles and Mitchell 1990) or less (Beer et al. 2001; Bonoli 1997) than the three "worlds of capitalism”. From such debates two new types of welfare-state regimes emerged including the Southern welfare-state regime (Ferrera 1996) and the post-socialist welfare-state regime (Aidukaite 2004; Deacon 1993) that cannot be subsumed into one of the former categories, representing a heterogeneous group of countries in and of themselves. In light of such shortcomings, many scholars prefer using metric welfare-state regime characteristics such as GDP expenditure on welfare and the Gini coefficient in regard to inequalities in income distribution or the minimum wage (Schubert et al. 2008; Bonini 2008). Some of these new developments and criticisms have been incorporated in a modified version of Esping-Andersen’s typology (1999).

Although aware of the difficulties of classifying welfare-state regimes, we apply nevertheless the modified typology of Esping-Andersen $(1990,1999)$ in developing our thesis 
for two reasons. First, the model is of high heuristic value as a theoretical tool for comparisons between welfare-state regimes and social inequality. And second because empirical studies using different characteristics at the same time showed trade-offs between different social welfare models (see Hega and Hokenmaier 2002 for an example of a trade-off between social and education policy). It is therefore highly interesting and relevant to focus on typologies that have been derived via the analyses of an extensive set of characteristics. In analyzing how welfare-state regimes vary in their wealth distribution policies, the conceptual framework developed encompasses five types: (1) the conservative, (2) liberal, and (3) socialdemocratic welfare-state regimes (Esping-Andersen 1990), as well as (4) the family-oriented welfare-state regime (Esping-Andersen 1999) and (5) post-socialist welfare-state regime (Deacon 1993; Blossfeld et al. 2008).

\section{How Welfare-State Regimes Impact Subjective Well-Being}

In order to theorize the link between types of welfare-state regime and subjective well-being (SWB), it is necessary to explore how social policies affect major individual determinants of SWB and, in particular, how the welfare-state model compensates for disadvantages in terms of social inequality and social stratification, including, for example, how the system supports lower-status citizens. As previously outlined, welfare-state policies particularly address income disparities (Esping-Andersen 1990) and explicitly or implicitly strive to provide a minimum income, which can allow for decent food and housing, thereby ensuring that nobody in society is disadvantaged when it comes to basic needs. Strong welfare-state regimes which strongly strive to guarantee a minimum standard of living for all citizens should also be characterized by higher SWB levels (cf. Korpi and Palme, 1998). But why should that be the case? Firstly, for the average SWB level in society, the SWB of socially disadvantaged groups is of crucial concern, as they are characterized by the lowest levels of SWB. If welfare-state 
regimes succeed in alleviating social and economic precarity, socially disadvantaged groups should almost disappear and it would be expected that their SWB levels will be higher than in comparative countries with weak welfare-state regimes. Wilkinson and Pickett (2010) argue along these lines when they stress that social inequalities in terms of differential access to goods, services and positions, signaled by income inequalities and a high degree of social stratification, go hand-in-hand with the social disadvantage of lower and middle class groups (see Zagorski et al. 2014).

The above point made by Wilkinson and Pickett (2010) is linked to a second contention related to the perception of inequalities as well as attitudes towards such inequalities. Income inequality is perceived as unjust and harmful by most in society. The perception of unjust inequalities may correspond to reduced SWB levels (Hanssen 2011; Noll and Weick 2012). Those in society who adhere to inequality-averse values and attitudes perceive inequalities as a social problem and will show reduced SWB if they perceive high levels of inequality. It would follow then that welfare-state regimes, which are weaker in diminishing inequality, will exhibit lower SWB. This is supported by Noll and Weick (2012) who find a positive correlation between the acceptance of social inequalities and SWB. Findings from Alesina et al. (2004) moreover suggest that the link between inequality and happiness is moderated by principals of social inequality that relate to the question of whether people are averse towards inequalities.

A third line of thought comes from social comparison theory (Festinger 1954) and reference group theory (Merton and Kitt 1950; Hyman and Singer 1968): higher inequalities and strong social stratification correspond to higher levels of social comparison as well as higher levels of relative poverty, as more individuals perceive their living conditions as worse than those of other reference groups. Marx illustrates this social phenomenon as follows: “A house may be large or small; as long as the neighboring houses are likewise small, it satisfies all social requirement for a residence. But let there arise next to the little house a palace, and 
the little house shrinks to a hut. The little house now makes it clear that its inmate has no social position at all to maintain” (Marx [1847], p. 84). Zagorski et al. (2014) mention social comparison, yet reject it. They stress that society as a whole functions as a reference group and that in developed and prosperous societies the income of the generalized other (Berger et al. 1972) is perceived as far above the median. The consequences of this are that the average citizen perceives themselves to be disadvantaged in comparison to the rest of society which negatively impacts SWB levels. Recently Delhey and Kohler (2011) found a correlation between inequality, a present factor in diverse welfare-state regimes, and SWB, which counters earlier results from Veenhoven (2000) ${ }^{2}$. They use a measure for SWB inequality that corrects for instrument effects, rather than the use of standard deviation which has been common in most research. In light of recent evidence and our literature review, we hypothesize:

Hypothesis II: The welfare-state regime is linked to SWB levels.

This hypothesis is rather explorative and leaves the question of which welfare-state regime is associated with which SWB premium or penalty aside. As we attempt to find answers to that question, we add a theoretical scenario to our general hypothesis. Of all welfare-state regimes, the social-democratic or Scandinavian type (e.g. Norway, Sweden) is making the clearest effort to provide its citizens with a socially and economically secure life, redistributing wealth by employing tax laws and security institutions (Esping-Andersen 1990). Therefore countries in this category will exhibit the greatest SWB premium. Conservative welfare-states such as Germany and Luxembourg do not redistribute wealth to the same extent. They tend to display lower levels of social welfare, using the principle of subsidiarity where the state only

$2 \quad$ Veenhoven (2000) found no effects of the welfare state and its size on the societal SWB level. This null finding is explained through referring to the need fulfillment thesis. From this perspective, the question of income inequality is insignificant and does not pose a problem as long as needs are fulfilled. However in line with Diener and Lucas (2000), it is not only a question of how the welfare state develops and implements policy, but also how this is perceived by individuals in terms of whether they recognize that specific needs are being fulfilled. 
intervenes when, for example, citizens are unable to find gainful employment or source financial means from family members. Comparing this to the social-democratic welfare-state regime, the conservative welfare-state regime will experience a SWB penalty. In contrast to the social-democratic and conservative welfare-state regimes, the principle of the free market is the bedrock of the liberal welfare-state model (Esping-Andersen 1990) exemplified in Europe with the UK as well as Switzerland, although, as noted by Trampusch (2010), the latter also includes some characteristics of the conservative type. The liberal welfare-state provides minimal support and aims to intervene as little as possible. Compared to the socialdemocratic welfare-state regime we would expect the SWB penalty to be relatively small. Family-oriented or Southern welfare-state regimes such as Greece and Portugal are characterized by the prominent role of families in providing welfare and generally high levels of inequality and stratification. The state provides only limited support, and clientelism, as well as patronage, are common (Ferrera 1996). Consequently, countries belonging to this type will also experience a SWB penalty in comparison to the social-democratic model. While the welfare-state regimes discussed to this point are each characterized by how to produce or enable welfare, post-socialist welfare-states such as Estonia and Poland are rather diverse with regard to the ways they enable social welfare (Blossfeld et al. 2008). Although heterogeneity in this grouping of post-socialist welfare-states is high, they also share several characteristics relevant to the investigation of macro level SWB such as the gap between rich and poor, which feeds into considerable inequality alongside high levels of social stratification (Böhnke 2008; Bonini 2008). This set of characteristics is likely to yield the greatest SWB penalty compared to the social-democratic welfare-state regime.

The above shows that welfare-state regimes not only have an effect on macro SWB factors but also affect SWB indirectly through how they compensate for social disadvantage such as a low status. Welfare-state regimes that succeed in equalizing inequalities will display lower status effects on SWB and vice versa. The more unequal the distribution of income and 
other goods and positions is, the more individuals will compare themselves with others leading to frustration. It would be possible to counter this through, for example, social transfers that mitigate income and prestige differences between employment groups. This is towards ensuring that those resources that are decisive in attaining instrumental goals, in turn affecting SWB, are more equally distributed, which should lead to differences in the effect of status on SWB being reduced. Moreover social comparisons that would decrease SWB are also less likely to occur. We therefore hypothesize:

Hypothesis III: The welfare-state regime impacts the link between status and SWB.

The hypothetical scenario assumed is that the effect of status on SWB is lowest in socialdemocratic countries since those countries are best-placed to compensate for disadvantages that arise from inequalities. The opposite to this scenario is assumed to be represented by post-socialist countries as inequality is here highly prevalent and poorly compensated for by the welfare-state.

When analyzing any overlap between the welfare-state regime and SWB, economic prosperity needs to be taken into account. GDP is a key predictor of SWB on the macro level, and the welfare-state regimes under analysis differ in their level of affluence. ${ }^{3}$ The level of economic prosperity as well as the absence of unemployment, an indicator of economic strength, have proven to be essential determinants of the 'liveability' of a society (Veenhoven 2001; Böhnke 2008) and, moreover, been shown to be strong predictors of SWB (Inglehart and Klingemann 2000; Di Tella et al. 2003). Wealth also correlates with "human rights, equality, individualism, more schooling, more food, more doctors, greater income equality, and greater longevity” (Böhnke 2008:193; Diener and Suh 1999). Economic prosperity may impact both inequalities and SWB at the same time: "Developed nations have better

\footnotetext{
3 At the national level, the social-democratic welfare-state regime is positively correlated with GDP and the post-socialist welfare-state regime negatively correlated with GDP. The other welfare-state regimes were not significantly associated with GDP.
} 
infrastructure (schools, health, transport, law, welfare, etc.) providing welfare-state type benefits the poor would otherwise lack, which increases their SWB and further reduces inequality” (Zagorski et al. 2014, p. 1091). Those strong welfare-state regimes with high levels of decommodification, in particular social-democratic or northern welfare-states, are characterized by high economic prosperity (Schmid 2002). Many liberal welfare-state regimes however also share this characteristic, as indicated by GDP, but, in contrast, show low levels of decommodification. To investigate the true effects of the welfare-state regime on SWB, which demands controlling for the heterogeneity present within welfare-state regimes such as the post-socialist type, we will control for gross domestic product per capita (GDP) in our analyses, as this is a reliable indicator of economic prosperity (cf. Hadjar and Backes 2013). Modelling welfare-state regimes and GDP simultaneously will show the genuine effects of the welfare-state regime net of economic prosperity. This net effect will help gauge how welfarestate regimes in dealing with inequalities cause different SWB effects.

Finally, controlling for GDP also means taking into account unemployment rate as another important factor of subjective well-being (Veenhoven 2001; Böhnke 2008; Inglehart and Klingemann 2000; Di Tella et al. 2001, 2003). This link can be conceptualized considering (the aggregation of) certain micro-level mechanisms. Individual unemployment means exclusion from the society and has a strong negative impact on individual subjective well-being (Di Tella et al. 2001; Clark and Oswald 1994; Winkelmann and Winkelmann 1998), as it goes along with status decline, income loss, and psychological stress (Ervasti and Venetoklis 2010). Furthermore, unemployment rate is a widely perceived indicator of the current state of a society and in particular the economy that impacts individual perceptions and well-being (Terwey 1990; cf. Hadjar and Backes 2013). As GDP is linked to unemployment - the higher the GDP is, the lower is the unemployment in a country -, we can only include one of these factors in our models to avoid multicollinearity given the low number of macro level units. 


\section{Data, Measures, and Methods}

\subsection{Data}

We employ a cumulative data-set comprising all six waves (2002, 2004, 2006, 2008, 2010, and 2012) from the European Social Survey (ESS). The ESS is a cross-sectional survey conducted biannually with between 22 and 31 countries, depending on the wave. In total 36 countries have participated in the ESS since the first research wave. Our final models include between 116658 and 184059 cases drawn from between 28 and 34 countries. ${ }^{4}$ The pooling of data allows us to reduce the small sample bias at the macro level and to get more precise estimates at both the individual and macro level. However it is accepted selection bias may affect our results. Owing to this risk it was decided to only include respondents who are nonmigrants and between 25 and 80 years of age. Migrants who were not born in the respective country of analysis were excluded as individuals, since they are likely to have had a different socialization experience (see Hadjar and Backes 2013).

\subsection{Measures}

SWB is operationalized to reflect both affective and cognitive dimensions. The affective dimension of SWB, happiness, is measured by answers to the following question: "Taking all things together, how happy would you say you are?” Life satisfaction, the cognitive dimension, uses the following question: “All things considered, how satisfied are you with your life as a whole nowadays?” Both scales employ 11-point scales ranging from 0 "extremely unhappy/dissatisfied" to 10 "extremely happy/satisfied". Cronbach's $\alpha$ for this two-item scale is 0.83 .

The welfare-state regime, our key macro level predictor, has been categorized following the typologies of Esping-Andersen (1990, 1999) and Blossfeld et al. (2008): the

\footnotetext{
$4 \quad$ Countries included are Albania, Austria, Belgium, Bulgaria, Croatia, Cyprus, Czech Republic, Denmark, Germany, Estonia, Finland, France, Great Britain, Greece, Hungary, Iceland, Ireland, Israel, Italy, Kosovo, Lithuania, Luxembourg, Netherlands, Norway, Poland, Portugal, Russia, Slovenia, Slowakia, Spain, Sweden, Switzerland, Turkey, and Ukraine.
} 
social-democratic type (e.g. Sweden, Denmark), the conservative type (e.g. Germany, Luxembourg), the family-oriented type (e.g. Greece, Spain), the liberal type (e.g. the UK, Switzerland), and the post-socialist welfare states (e.g. Estonia, Poland). ${ }^{5}$

Because we are interested in the net effect of the welfare-state regime, we control for gross domestic product per capita (GDP) as a key indicator of economic prosperity. The GDP data collected by the World Bank (2015) relates to the gross value of all produced goods and services. We have standardized GDP per capita in U.S. dollars amending the respective equivalent rates of exchange per country and wave. From 2002 to 2012, Luxembourg and Norway show, on average, the highest GDP level, while Ukraine and Kosovo are at the other end of the scale. For the data analysis, we used the GDP log to normalize the distribution by reducing the weight of outliers and linearizing the SWB relationship.

Furthermore, we are using a Gini measure provided by Eurostat (2015). It considers equivalized disposable income before social transfers. Pensions are excluded from social transfers but they are included in this Gini measure. We chose this specific Gini measure, as we have respondents in our sample who have reached retirement age and whose income will in many cases be derived from pensions. We exclude social transfers so as to prevent multicollinearity with our welfare-state regime variables.

Our main individual level independent variable is occupational status measured through the International Socio-Economic Index (ISEI) by Harry Ganzeboom, Paul de Graaf, and Donald Treiman (1992). This scale ranges from 16 to 90. Illustrative scores are, for example, 90 for judges and 23 for garbage collectors (Ganzeboom and Treiman 1996). ${ }^{6}$

We further control for other important predictors of SWB: Education (net of status) is linked to cognitive capabilities to satisfy ones needs, and thus, to SWB (Hadjar et. al. 2008).

$5 \quad$ For a welfare-state regime classification of the countries please refer to table note $b$ in Table 1.

$6 \quad$ Modeling ISEI as having a linear effect is common practice. Clearly, it is attractive to entertain the idea of the non-linear effect of ISEI on SWB. For example, SWB premiums might decrease with increasing status. However, in following a cautious estimation strategy it was decided not to include a quadratic term of ISEI as there is no theoretical basis to do so. We will therefore slightly underestimate the effect of ISEI on SWB. 
We use a dichotomous variable that indicates whether someone has at least an ISCED level of 3a (upper secondary degree, high) and above. Moreover health has been found to be a major predictor of SWB and we therefore include a variable that measures subjective health using a scale ranging from 1 = "very good" to 5 = "very bad". We reversed the scale to allow for a more intuitive interpretation of estimates. As unemployment also proved to have a profound negative impact on SWB (e.g. Di Tella et al. 2001, 2003; Winkelmann and Winkelmann 1998), we control for this condition as well using a variable that indicates whether or not the respondent has been unemployed and was looking for a job during the last seven days before the interview. In addition, further controls are used in respect of gender and age as important drivers of SWB. We have here introduced age squared to account for the non-linear relationship of age with SWB. When pooling data from different research waves, estimates may well be driven by factors that were characteristic for that particular historical time. We therefore control for period effects using dummies to indicate the round of data collection. To further simplify the interpretation of our models, we standardize ( $\mathrm{z}$ transformation) our variables (see Table 1 for summary and descriptive information). 
Table 1 Descriptive statistics of research and control variables

\begin{tabular}{|c|c|c|}
\hline Variable & Operationalization & Descriptives $^{\mathrm{a}}$ \\
\hline Subjective Well-Being & $\begin{array}{l}\text { Two-item scale reflecting affectual and } \\
\text { cognitive dimension of SWB: happiness and } \\
\text { life satisfaction }\end{array}$ & $\begin{array}{l}\text { Mean (SD) } \\
6.62(2.11)\end{array}$ \\
\hline Status & International Socio-Economic Index (ISEI) & $\begin{array}{c}\text { Mean(SD) } \\
42.95(17.76)\end{array}$ \\
\hline GDP & Logged GDP per capita, by country, and period & $\begin{array}{l}\text { Mean(SD) } \\
9.93(0.77)\end{array}$ \\
\hline Gini & $\begin{array}{c}\text { Gini coefficient of equivalized disposable } \\
\text { income before social transfers by country and } \\
\text { period (pensions excluded from social transfers, } \\
\text { i.e., they are included in this Gini measure) }\end{array}$ & $\begin{array}{l}\text { Mean(SD) } \\
36.00(2.94)\end{array}$ \\
\hline Welfare-state regimes & $\begin{array}{l}\text { Welfare-state regime, based on Esping- } \\
\text { Andersen }(1990,1999) \text { and } \\
\text { Blossfeld et al. (2008) }\end{array}$ & $\begin{array}{c}\text { Conservative }^{\mathrm{b}}=27.51 \% \\
\text { Social-democratic }=4.19 \% \\
\text { Family-oriented }=19.64 \% \\
\text { Liberal }=12.54 \% \\
\text { Post-socialist }=36.11 \% \\
\text { (proportions on the individual } \\
\text { level) }\end{array}$ \\
\hline Educational level & $\begin{array}{l}\text { Proportion of people with at least ISCED level } \\
\text { 3a (upper secondary degree, high) and above }\end{array}$ & $\begin{array}{c}\text { ISCED level 3a and above }= \\
52.03 \% \\
\text { ISCED level below 3a = } \\
47.97 \%\end{array}$ \\
\hline Age & Age in years & $\begin{array}{c}\text { Mean(SD) } \\
50.88(12.35)\end{array}$ \\
\hline Age, squared & Age in years, squared & $\begin{array}{c}\text { Mean (SD) } \\
2741.71(1289.23)\end{array}$ \\
\hline Subjective general health & (1 very bad, 5 very good) & $\begin{array}{l}\text { Mean(SD) } \\
3.56(0.89)\end{array}$ \\
\hline Unemployed & $\begin{array}{l}\text { Unemployed, looking actively for job (last } 7 \\
\text { days) vs. all other }\end{array}$ & $4.00 \%$ \\
\hline Female & Self-reported sex & $54.16 \%$ \\
\hline
\end{tabular}

a. Weighted (population size weight, design weight). $n$ is between 171,743 and 184,222 for all level 1 variables.

b. Conservative: Austria, Belgium, France, Germany, Israel, Luxembourg, and the Netherlands; Social-democratic: Denmark, Finland, Iceland, Norway, and Sweden; Family-oriented: Cyprus, Greece, Ireland, Italy, Portugal, Spain, and Turkey; Liberal: Great Britain, and Switzerland; Post-socialist: Albania, Bulgaria, Croatia, Czech Republic, Estonia, Hungary, Kosovo, Lithuania, Poland, Russia, Slovenia, Slowakia, and Ukraine. 


\subsection{Methods}

\subsubsection{Analytical Strategy}

We employ multilevel models with individuals who reside within countries representing diverse welfare-state types to test our hypotheses. We do not assume country-variant effects as regards our key variables on SWB. This is mainly because there is no conceptual and empirical reason to assume that any random effect will be uncorrelated with any one of our explanatory variables. This said there will be variation in the effects across welfare-state regimes and country-specific effects of unobserved variables. We therefore estimate random intercept models using robust standard errors (Eicker-Huber-White method). This allows for relaxing assumptions about the homoskedasticity and normality of the error terms in estimating consistent results.

The first model (Model I, null model) serves to gauge the amount of variance on level 2. We then extend the model to include all variables on level 1 (Model II). To analyze the effects of the welfare-state regime, the respective variables are entered next (Model III). Our main hypothesis that there will be a status-well-being link that varies across different welfarestate regimes implies a cross-level interaction between status and welfare-state regime. To carefully explore this relationship we add an interaction between our status variable and the welfare-state regime variable in Model IV. ${ }^{7}$ As previously argued, the affluence of a society is likely to affect the level of SWB and we therefore add the logged gross domestic capita per year as a control separately for each country in our data set (Model V). To rule out the effects of income inequality that would presumably partly or entirely explain inequalities in SWB, we further include the distribution of income using the Gini coefficient which includes pensions but before social transfers in Model VI.

\footnotetext{
7 As interaction effects are at times hard to interpret, we further ran pooled fixed effects regression models for the sets of welfare-state regimes to explore the complexity of our core models (tables available on request).
} 


\subsubsection{Influential Level Two Units}

A problem may be that individual countries exhibit value patterns or other specific characteristics, such as high unemployment rates that bias the results. Furthermore, countries on level 2 are not a random sample and comparably few. If some countries prove to be outliers, this may bias the results considerably. This may either be directly via variables on level 2 or indirectly, through countries acting as moderators. To test whether our findings are affected by outliers on the country level, we analyze the standardized differences in parameter estimates (DFBETAs) between the model using the full data set and the subset of models that excludes one level-two unit. Following Verbakel (2013), we calculate DFBETAs for all variables, in all models presented. As we are interested in unbiased estimates of status, we focus on this variable in each of the models.

In the full model (Model VI) the DFBETAs for status indicate that Finland, Sweden, and Norway differ from the other countries. They also have Cook’s D values which are above the calculated cut off value for the level-two units of $0.143(0.175,0.338$, and 0.613 respectively). We reran Model VI excluding in turn the respective countries but did not find substantial changes in the estimation of the status variable or other variables.

We are aware that this procedure provides only a statistical answer to the question of whether it is adequate to analyze various countries in one model. Giving a substantial answer would require unpacking the meaning of every variable for every country. While this would certainly yield interesting insights for the construction of country specific questionnaires, our focus in this study rests elsewhere. 


\section{Results}

The results of the multilevel analysis are presented in Table 2. The null model (Model I) shows that $21 \%$ of the variance in subjective well-being (SWB) is on level 2. This supports our analytical strategy where we model individuals nested within countries. ${ }^{8}$ Model II reveals that status has a positive effect on SWB, controlling for various important factors, thus providing evidence for Hypothesis I. Education and being a female are positively associated with SWB (Table 2, individual level 2 controls). Subjective health status is positively related to SWB, indicating that the better someone evaluates their health to be, the higher their SWB level. Unemployment is negatively associated with SWB. The effect of age on SWB follows a U-shaped curve (Table 2, individual level 2 controls).

In Model III, these effects remain, in the main, unchanged with the inclusion of the welfare-state regime variable. As hypothesized, welfare-state regimes differ in their effects on SWB as was expected in Hypothesis II. Using social-democratic countries as a baseline, living in a post-socialist welfare-state regime causes the greatest SWB penalty followed by family-oriented, conservative, and liberal welfare-state regimes. These findings corroborate those expectations that were based on the theoretical scenario derived from Hypothesis II. Adding a cross-level interaction between status and the welfare-state regime in Model IV changes the interpretation of these variables. The fixed effect of ISEI is now the main effect of status on SWB in social-democratic countries only. This model thus shows that status does have a negative effect on SWB in social-democratic countries. The effects of the welfare-state regime follow the pattern outlined for Model III but have to be interpreted differently. Compared to individuals in social-democratic welfare-state regimes, respondents with an average status level experience the greatest SWB penalty when living in a post-socialist welfare-state regime. The interaction terms reveal how welfare-state regimes differ with regard to how they shape status effects on SWB. Using the example of living in a post-

$8 \quad$ We furthermore calculated empirical Bayes estimates of the random intercepts showing considerable variation in SWB across countries. This further supports our analytic strategy. 
socialist welfare-state regime, we find that although living in a post-socialist country is associated with, on average, low SWB levels, SWB increases by .15 of a standard deviation for an individual with a standardized ISEI of one standard deviation (above the mean) in comparison to social-democratic regimes. This corroborates our hypothesis III.

An important question is whether welfare-state regime effects conceal the effects of relative affluence and income inequality. Model V includes gross domestic product per capita to test this concern. In line with previous research, GDP has a positive effect on SWB. While the estimates for the control variables remain substantially unchanged with reference to the main effect of status and the cross-level interactions, the effects for welfare-state regime change. While still being affected by the greatest SWB penalty, the effect of the welfare-state regime for those living in post-socialist societies is then smaller. These changes to Model IV suggest that, in part, the effects of the welfare-state regime can be explained by affluence, which may or may not have been fostered by the implementation of government policy. Similarly the effects for living in a liberal or family-oriented welfare-state regime become weaker, and even disappear, in the case of the conservative welfare-state regime. Adding the Gini coefficient in Model VI renders the main effect of status in social-democratic countries insignificant. Crucially the cross-level interactions remain significant. This is noteworthy as the inclusion of this variable leads to a sizable loss of cases. It may therefore be concluded that the estimates are robust. However, the main effect for the liberal welfare-state regime is no longer significant and the main effects for the family-oriented and post-socialist welfarestate regimes become weaker. An important finding in Model VI is that the level of inequality is negatively associated with SWB, as was expected.

Overall, our results show that welfare-state regimes affect the SWB of their incumbents and moderate the effects of status on SWB, net of affluence and income inequality. 
Table 2 Effects on SWB, multilevel models with random intercepts, and robust standard errors. All continuous research variables are standardized.

\begin{tabular}{|c|c|c|c|c|c|c|}
\hline & $\begin{array}{c}\text { Model I } \\
(\mathrm{n}=184,059) \\
(\mathrm{N}=34)\end{array}$ & $\begin{array}{c}\text { Model II } \\
(\mathrm{n}=170,496) \\
(\mathrm{N}=34)\end{array}$ & $\begin{array}{c}\text { Model III } \\
(\mathrm{n}=170,496) \\
(\mathrm{N}=34)\end{array}$ & $\begin{array}{c}\text { Model IV } \\
(\mathrm{n}=170,496) \\
(\mathrm{N}=34)\end{array}$ & $\begin{array}{c}\text { Model V } \\
(\mathrm{n}=170,496) \\
(\mathrm{N}=34)\end{array}$ & $\begin{array}{c}\text { Model VI } \\
(\mathrm{n}=116,658) \\
(\mathrm{N}=28)\end{array}$ \\
\hline \multicolumn{7}{|l|}{ Fixed effects } \\
\hline ISEI & & $\begin{array}{c}0.059^{* * *} \\
(0.01)\end{array}$ & $\begin{array}{c}0.058^{* * *} \\
(0.01)\end{array}$ & $\begin{array}{c}-0.025^{*} \\
(0.01)\end{array}$ & $\begin{array}{c}-0.025^{*} \\
(0.01)\end{array}$ & $\begin{array}{c}-0.020 \\
(0.01)\end{array}$ \\
\hline \multicolumn{7}{|l|}{ Macro level effects } \\
\hline \multicolumn{7}{|c|}{ Welfare-state regime [Ref: social-democratic] } \\
\hline Conservative & & & $\begin{array}{c}-0.437^{* * *} \\
(0.08)\end{array}$ & $\begin{array}{c}-0.441^{* * *} \\
(0.08)\end{array}$ & $\begin{array}{c}-0.131 \\
(0.07)\end{array}$ & $\begin{array}{c}-0.125 \\
(0.09)\end{array}$ \\
\hline Family-oriented & & & $\begin{array}{c}-0.559^{* * * *} \\
(0.10)\end{array}$ & $\begin{array}{c}-0.576^{* * * *} \\
(0.10)\end{array}$ & $\begin{array}{c}-0.371^{* * *} \\
(0.10)\end{array}$ & $\begin{array}{c}-0.324^{* * *} \\
(0.12)\end{array}$ \\
\hline Liberal & & & $\begin{array}{c}-0.312^{*} \\
(0.14)\end{array}$ & $\begin{array}{c}-0.327^{*} \\
(0.14)\end{array}$ & $\begin{array}{c}-0.215^{* *} \\
(0.08)\end{array}$ & $\begin{array}{c}-0.195 \\
(0.10)\end{array}$ \\
\hline Post-socialist & & & $\begin{array}{c}-0.694^{* * * *} \\
(0.08)\end{array}$ & $\begin{array}{c}-0.707^{* * * *} \\
(0.08)\end{array}$ & $\begin{array}{c}-0.386^{* * *} \\
(0.07)\end{array}$ & $\begin{array}{c}-0.380^{* * * *} \\
(0.09)\end{array}$ \\
\hline \multicolumn{7}{|l|}{ Macro level controls } \\
\hline GDP & & & & & $\begin{array}{c}0.203^{* * *} \\
(0.03)\end{array}$ & $\begin{array}{c}0.212^{* * *} \\
(0.06)\end{array}$ \\
\hline Gini & & & & & & $\begin{array}{c}-0.086^{* *} \\
(0.03)\end{array}$ \\
\hline \multicolumn{7}{|c|}{ Cross-level interactions } \\
\hline Conservative $\times$ ISEI & & & & $\begin{array}{c}0.069^{* * *} \\
(0.02)\end{array}$ & $\begin{array}{c}0.069^{* * *} \\
(0.02)\end{array}$ & $\begin{array}{c}0.074^{* *} \\
(0.02)\end{array}$ \\
\hline Family-oriented $\times$ ISEI & & & & $\begin{array}{c}0.076^{* * * *} \\
(0.02)\end{array}$ & $\begin{array}{c}0.076^{* * * *} \\
(0.02)\end{array}$ & $\begin{array}{c}0.073^{* * * *} \\
(0.02)\end{array}$ \\
\hline Liberal $\times$ ISEI & & & & $\begin{array}{l}0.068^{*} \\
(0.03)\end{array}$ & $\begin{array}{l}0.068^{*} \\
(0.03)\end{array}$ & $\begin{array}{c}0.071^{* * * *} \\
(0.02)\end{array}$ \\
\hline Post-socialist $\times$ ISEI & & & & $\begin{array}{c}0.146^{* * *} \\
(0.02)\end{array}$ & $\begin{array}{c}0.146^{* * *} \\
(0.02)\end{array}$ & $\begin{array}{c}0.154^{* * *} \\
(0.02)\end{array}$ \\
\hline \multicolumn{7}{|l|}{ Individual level controls } \\
\hline Education & & $\begin{array}{c}0.044^{* *} \\
(0.01)\end{array}$ & $\begin{array}{l}0.045^{* *} \\
(0.01)\end{array}$ & $\begin{array}{l}0.044^{* *} \\
(0.01)\end{array}$ & $\begin{array}{l}0.044^{* *} \\
(0.01)\end{array}$ & $\begin{array}{c}0.039^{* *} \\
(0.01)\end{array}$ \\
\hline Subjective health & & $\begin{array}{c}0.333^{* * *} \\
(0.01)\end{array}$ & $\begin{array}{c}0.332^{* * * *} \\
(0.01)\end{array}$ & $\begin{array}{c}0.332^{* * * *} \\
(0.01)\end{array}$ & $\begin{array}{c}0.332^{* * * *} \\
(0.01)\end{array}$ & $\begin{array}{c}0.328^{* * * *} \\
(0.01)\end{array}$ \\
\hline Unemployed & & $\begin{array}{c}-0.503^{* * *} \\
(0.04)\end{array}$ & $\begin{array}{c}-0.497^{* * * *} \\
(0.04)\end{array}$ & $\begin{array}{c}-0.492^{* * * *} \\
(0.04)\end{array}$ & $\begin{array}{c}-0.492^{* * *} \\
(0.04)\end{array}$ & $\begin{array}{c}-0.488^{* * * *} \\
(0.03)\end{array}$ \\
\hline Female & & $\begin{array}{c}0.041^{* * * *} \\
(0.01)\end{array}$ & $\begin{array}{c}0.041^{* * * *} \\
(0.01)\end{array}$ & $\begin{array}{c}0.036^{* * *} \\
(0.01)\end{array}$ & $\begin{array}{c}0.036^{* * *} \\
(0.01)\end{array}$ & $\begin{array}{c}0.032^{* * * *} \\
(0.01)\end{array}$ \\
\hline Age & & $\begin{array}{c}-0.018^{* * *} \\
(0.00)\end{array}$ & $\begin{array}{c}-0.018^{* * * *} \\
(0.00)\end{array}$ & $\begin{array}{c}-0.018^{* * * *} \\
(0.00)\end{array}$ & $\begin{array}{c}-0.018^{* * *} \\
(0.00)\end{array}$ & $\begin{array}{c}-0.021^{* * *} \\
(0.00)\end{array}$ \\
\hline Age, squared & & $\begin{array}{c}0.000^{* * * *} \\
(0.00)\end{array}$ & $\begin{array}{c}0.000^{* * * *} \\
(0.00)\end{array}$ & $\begin{array}{c}0.000^{* * * *} \\
(0.00)\end{array}$ & $\begin{array}{c}0.000^{* * * *} \\
(0.00)\end{array}$ & $\begin{array}{c}0.000^{* * * *} \\
(0.00)\end{array}$ \\
\hline \multicolumn{7}{|c|}{ ESS round [Ref: Round 2002] } \\
\hline 2004 & & $\begin{array}{l}0.014 \\
(0.02)\end{array}$ & $\begin{array}{l}0.014 \\
(0.02)\end{array}$ & $\begin{array}{l}0.014 \\
(0.02)\end{array}$ & $\begin{array}{l}0.014 \\
(0.02)\end{array}$ & base $^{a}$ \\
\hline 2006 & & $\begin{array}{l}0.014 \\
(0.03)\end{array}$ & $\begin{array}{l}0.013 \\
(0.03)\end{array}$ & $\begin{array}{l}0.014 \\
(0.03)\end{array}$ & $\begin{array}{l}0.015 \\
(0.03)\end{array}$ & $\begin{array}{c}-0.019 \\
(0.03)\end{array}$ \\
\hline 2008 & & $\begin{array}{c}-0.003 \\
(0.03)\end{array}$ & $\begin{array}{c}-0.004 \\
(0.03)\end{array}$ & $\begin{array}{c}-0.002 \\
(0.03)\end{array}$ & $\begin{array}{c}-0.002 \\
(0.03)\end{array}$ & $\begin{array}{l}-0.050 \\
(0.03)\end{array}$ \\
\hline 2010 & & $\begin{array}{l}0.023 \\
(0.05)\end{array}$ & $\begin{array}{l}0.023 \\
(0.05)\end{array}$ & $\begin{array}{l}0.024 \\
(0.05)\end{array}$ & $\begin{array}{l}0.024 \\
(0.05)\end{array}$ & $\begin{array}{c}-0.028 \\
(0.05)\end{array}$ \\
\hline 2012 & & $\begin{array}{l}0.058 \\
(0.04)\end{array}$ & $\begin{array}{l}0.057 \\
(0.04)\end{array}$ & $\begin{array}{l}0.061 \\
(0.04)\end{array}$ & $\begin{array}{l}0.062 \\
(0.04)\end{array}$ & $\begin{array}{c}-0.007 \\
(0.04)\end{array}$ \\
\hline Constant & $\begin{array}{c}-0.032 \\
(0.08) \\
\end{array}$ & $\begin{array}{c}-0.961^{* * *} \\
(0.12)\end{array}$ & $\begin{array}{c}-0.478^{* * *} \\
(0.10) \\
\end{array}$ & $\begin{array}{c}-0.458^{* * *} \\
(0.10)\end{array}$ & $\begin{array}{c}-0.654^{* * *} \\
(0.12) \\
\end{array}$ & $\begin{array}{c}-0.569^{* * *} \\
(0.16) \\
\end{array}$ \\
\hline $\begin{array}{l}\text { Random effect } \\
\text { SD constant }\end{array}$ & 0.460 & 0.376 & 0.257 & 0.254 & 0.169 & 0.193 \\
\hline Wald Chi-Square & - & 1194.817 & $14,656.226$ & $24,656.762$ & $76,864.105$ & $191,158.107$ \\
\hline $\mathrm{P}>$ Chi-Square & 0 & 0 & 0 & 0 & 0 & 0 \\
\hline BIC & $479,967.8$ & $417,837.9$ & $417,615.5$ & $417,024.5$ & $417,009.1$ & $278,866.4$ \\
\hline
\end{tabular}


a. There is no harmonized Gini measure of equalized disposable income, excluding social transfers but including pensions available for 2002. Therefore all ESS data for this year may not be used in estimating Model VI.

\section{Discussion and Conclusions}

We have studied how welfare-state regimes shape societal subjective well-being (SWB) levels as well as the relationship between status and SWB on the individual level, analyzing European Social Survey data from 34 countries carried out over a twelve year period. ${ }^{9}$

First, we considered status as an individual level determinant of SWB. Our multilevel analysis and results showed a positive correlation between status and SWB, thereby corroborating Hypothesis I. Status exhibited a significant effect if we simultaneously considered other important individual level determinants such as education, age and health. This large effect in respect of total education, caused presumably because it relates to possession of the cognitive abilities to know and satisfy one's needs, may be partly rooted in financial resources and prestige, both of which are instruments in the production of wellbeing, according to social production function theory (Ormel et al., 1999). However, as the complex multilevel models, including cross-level interactions show, status is not per se linked to SWB, but rather the impact it causes depends on the welfare-state regime. However, before discussing the related hypothesis to this, it is first necessary to evaluate the findings in regard to Hypothesis II which assumes that the type of welfare-state regime is linked to SWB levels. Countries being classified as social-democratic welfare states showed the highest SWB levels, while in our basic models all other welfare-state regimes display lower macro level SWB (see also Table A2). Through controlling for economic prosperity (GDP per capita) and income inequality (Gini coefficient), it was found that family-oriented and post-socialist countries have a significantly lower level of SWB than social-democratic countries. All in all, these findings strongly corroborate Hypothesis II. Furthermore, there is some evidence to support assumptions developed in the theoretical scenario above to exemplify and clarify hypothesis

$9 \quad$ Our final model contains only 28 countries as we do not have information on the Gini for all countries and periods (see note $a$ in Table 2). 
II. While, as expected, the social-democratic welfare-state regime type was associated with the highest SWB level, the conservative welfare-state regime was not the polar opposite. This may owe to conservative regimes, still characterized by relatively strong welfare measures, having, at least to some extent, the power to provide a decent standard of living. The findings also support Hypothesis III in that the welfare-state regime indeed proved to have an impact on the relationship between status and SWB. These results clearly indicate that the statusSWB link, when controlling both for GDP and the Gini coefficient, is weakest in countries with a social-democratic welfare-state regime, whereas in the conservative, family-oriented, liberal and post-socialist types the status-SWB link is significantly stronger. This backs our contention that social-democratic welfare states seem to perform best in providing a decent standard of life to all through compensating for disadvantages that are salient for SWB. This does not only refer to generally enabling a decent standard of life alongside policies to reduce inequality as the effect remains significant even when controlling for economic strength and inequality, but may hint at specific social circumstances and their subjective evaluation. If individuals feel that there is a low level of inequality where the state compensates for individual disadvantages and creates the conditions for a good life, this may increase levels of SWB as citizens arrive at more positive affective and cognitive evaluations of their lives. Moreover a state that successfully supports 'happiness for all' may serve to reduce the impact critical life events have on SWB. Moreover, as our Gini measure relates to disposable income, countries also seem to equalize or increase inequality with regard to SWB by policy measures other than direct monetary transfers, such as providing services and goods.

These findings show that welfare-state regimes are linked to SWB and that this relationship depends on how welfare-state regimes deal with inequality, which ties in with recent research that emphasizes a negative link between income inequality and SWB (e.g. Alesina et al. 2004; cf. Zagorski et al. 2014), which should merit more detailed exploration in future research. 
The significant differences in how welfare-state regimes shape SWB and affect the relationship between status and SWB make the case for using welfare-state regimes typologies as a heuristic tool in researching inequalities. As with any typology, the placing of countries into these categories will have to be scrutinized and adapted against the backdrop of empirical evidence and theoretical development, which will prevent the results from being driven by a few countries coded in a particular way. In addition we conducted a level two outlier analysis so as to estimate the extent of bias introduced by influential countries. The findings demonstrate that welfare-state regimes appear to have empirical correlates, which is an approach demanded by Arts and Gelissen (2010). This should be investigated further as it was only possible to consider a limited number of macro level characteristics, owing to the number of countries covered in ESS data being rather low $(\mathrm{N}=34)$. Consequently bias due to omitted variables may affect some of the findings. Nonetheless, our results encourage further research that employs established and new welfare-state regime classifications (e.g. EspingAndersen 1990, 1999; Ferrera 1996).

Our findings concerning welfare-state differences in the relationship between status and SWB also point towards the need to be more cautious in social science research when studying status across multiple countries. However it is debatable if a comparison of status between countries makes sense, as the differences in prestige, living conditions and total income, for example, between a manual worker and a medical doctor, may be rather different in a social-democratic and a conservative welfare-state regime. In other words status is likely to mean something different in regard to both objective and subjective living conditions when tested in the welfare-state regimes present in, for example, Sweden and Germany. There are diverse conceptual positions on status in social science literature covering aspects of prestige and economic position. As well as the moderate number of countries under investigation in this analysis, further conceptual and methodological limitations need to be mentioned. In our analyses, we left cultural mechanisms aside and focused on material issues. Future research 
should more strongly emphasize cultural differences in the perception and evaluation of inequality, but also the perception of SWB as a relative concept including a comparison of past and 'idealized' future conditions. For example, comparing Europe and the US, the more critical views of Europeans on inequality seem to be reflected in lower happiness levels and, in particular, higher social inequalities with regard to how happy different social groups are (Alesina et al. 2004). Thus, it would be interesting for future research to look further afield than the European context. A general methodological limitation of our study relates to the cross-sectional nature of our analysis with the data-sets pooled from the ESS. Panel data would allow for the reconstruction of how SWB or the relation between status and SWB changes, for example, following policy reforms, and how living conditions, as well as critical life events, shape SWB. Furthermore, although the measure of SWB consists of one item for life satisfaction and one item for happiness, it could be argued that it does not constitute a psycho-metrically adequate construct of SWB.

In conclusion, our findings indicate that Scandinavian countries perform best in the provision of a good standard of life as well as 'happiness for all', and, moreover, that this is not just rooted in strong anti-inequality measures. This study should motivate further research on the complex relationship between inequality and SWB in diverse welfare-state regimes, which is highly relevant for policy-makers across Europe as they deliberate upon how to create and maintain the conditions for a good standard of life in spite of economic pressures. 


\section{Appendix}

Table A1 Effects on SWB per welfare-state regime, multilevel models with random intercepts and robust standard errors. All continuous research variables are standardized.

\begin{tabular}{|c|c|c|c|c|c|}
\hline & $\begin{array}{c}\text { Model IIa } \\
\text { Conservative } \\
\text { WSR } \\
(\mathrm{n}=36,438) \\
(\mathrm{N}=7)\end{array}$ & $\begin{array}{c}\text { Model IIb } \\
\text { Social-democratic } \\
\text { WSR } \\
(\mathrm{n}=28,114) \\
(\mathrm{N}=5)\end{array}$ & $\begin{array}{c}\text { Model IIc } \\
\text { Family-oriented } \\
\text { WSR } \\
(\mathrm{n}=31,640) \\
(\mathrm{N}=7) \\
\end{array}$ & $\begin{array}{c}\text { Model IId } \\
\text { Liberal WSR } \\
(\mathrm{n}=21,003) \\
(\mathrm{N}=3)\end{array}$ & $\begin{array}{c}\text { Model IIe } \\
\text { Post-socialist } \\
\text { WSR } \\
(\mathrm{n}=53,301) \\
(\mathrm{N}=13) \\
\end{array}$ \\
\hline \multicolumn{6}{|l|}{ Fixed effects } \\
\hline ISEI & $\begin{array}{c}0.044^{* * *} \\
(0.01)\end{array}$ & $\begin{array}{l}0.005 \\
(0.01)\end{array}$ & $\begin{array}{c}0.061^{* * * *} \\
(0.01)\end{array}$ & $\begin{array}{l}0.047^{*} \\
(0.02)\end{array}$ & $\begin{array}{c}0.096^{* * *} \\
(0.01)\end{array}$ \\
\hline Education & $\begin{array}{l}0.053^{*} \\
(0.03)\end{array}$ & $\begin{array}{c}-0.045 \\
(0.03)\end{array}$ & $\begin{array}{l}0.025 \\
(0.02)\end{array}$ & $\begin{array}{l}0.042 \\
(0.03)\end{array}$ & $\begin{array}{c}0.107^{* * *} \\
(0.02)\end{array}$ \\
\hline Subjective health & $\begin{array}{c}0.314^{* * *} \\
(0.02)\end{array}$ & $\begin{array}{c}0.271^{* * *} \\
(0.03)\end{array}$ & $\begin{array}{c}0.305^{* * *} \\
(0.03)\end{array}$ & $\begin{array}{c}0.321^{* * * *} \\
(0.03)\end{array}$ & $\begin{array}{c}0.388^{* * * *} \\
(0.01)\end{array}$ \\
\hline Unemployed & $\begin{array}{c}-0.551^{* * *} \\
(0.08)\end{array}$ & $\begin{array}{c}-0.341^{* * *} \\
(0.03)\end{array}$ & $\begin{array}{c}-0.449^{* * * *} \\
(0.07)\end{array}$ & $\begin{array}{c}-0.562^{* * *} \\
(0.02)\end{array}$ & $\begin{array}{c}-0.502^{* * * *} \\
(0.04)\end{array}$ \\
\hline Female & $\begin{array}{c}0.051^{* * *} \\
(0.01)\end{array}$ & $\begin{array}{c}0.082^{* * * *} \\
(0.02)\end{array}$ & $\begin{array}{c}-0.010 \\
(0.01)\end{array}$ & $\begin{array}{l}0.017 \\
(0.02)\end{array}$ & $\begin{array}{c}0.049^{* * * *} \\
(0.01)\end{array}$ \\
\hline Age & $\begin{array}{c}-0.014^{*} \\
(0.01)\end{array}$ & $\begin{array}{c}-0.012^{* * * *} \\
(0.00)\end{array}$ & $\begin{array}{c}-0.022^{* * * *} \\
(0.00)\end{array}$ & $\begin{array}{c}-0.021^{*} \\
(0.01)\end{array}$ & $\begin{array}{c}-0.030^{* * * *} \\
(0.00)\end{array}$ \\
\hline Age, squared & $\begin{array}{l}0.000^{* *} \\
(0.00)\end{array}$ & $\begin{array}{c}0.000^{* * *} \\
(0.00)\end{array}$ & $\begin{array}{c}0.000^{* * *} \\
(0.00)\end{array}$ & $\begin{array}{l}0.000^{*} \\
(0.00)\end{array}$ & $\begin{array}{c}0.000^{* * *} \\
(0.00)\end{array}$ \\
\hline \multicolumn{6}{|c|}{ ESS round [Ref: round 2002] } \\
\hline 2004 & $\begin{array}{c}-0.017 \\
(0.04)\end{array}$ & $\begin{array}{l}0.014^{*} \\
(0.01)\end{array}$ & $\begin{array}{l}0.041 \\
(0.06)\end{array}$ & $\begin{array}{c}-0.003 \\
(0.03)\end{array}$ & $\begin{array}{l}0.060 \\
(0.08)\end{array}$ \\
\hline 2006 & $\begin{array}{l}-0.029 \\
(0.04)\end{array}$ & $\begin{array}{l}0.010 \\
(0.01)\end{array}$ & $\begin{array}{l}0.003 \\
(0.06)\end{array}$ & $\begin{array}{l}-0.021 \\
(0.02)\end{array}$ & $\begin{array}{l}0.143 \\
(0.10)\end{array}$ \\
\hline 2008 & $\begin{array}{l}-0.013 \\
(0.05)\end{array}$ & $\begin{array}{l}0.025^{*} \\
(0.01)\end{array}$ & $\begin{array}{l}-0.106 \\
(0.07)\end{array}$ & $\begin{array}{c}-0.022 \\
(0.03)\end{array}$ & $\begin{array}{l}0.144 \\
(0.12)\end{array}$ \\
\hline 2010 & $\begin{array}{l}0.038 \\
(0.06)\end{array}$ & $\begin{array}{l}0.020 \\
(0.02)\end{array}$ & $\begin{array}{l}-0.187 \\
(0.13)\end{array}$ & $\begin{array}{c}-0.028 \\
(0.04)\end{array}$ & $\begin{array}{l}0.226^{*} \\
(0.10)\end{array}$ \\
\hline 2012 & $\begin{array}{l}0.095 \\
(0.06)\end{array}$ & $\begin{array}{l}0.057^{*} \\
(0.03)\end{array}$ & $\begin{array}{l}-0.131 \\
(0.11)\end{array}$ & $\begin{array}{l}-0.011 \\
(0.04)\end{array}$ & $\begin{array}{l}0.237^{*} \\
(0.12)\end{array}$ \\
\hline Constant & $\begin{array}{c}-0.751^{* * *} \\
(0.15) \\
\end{array}$ & $\begin{array}{c}-0.369^{* * * *} \\
(0.10) \\
\end{array}$ & $\begin{array}{c}-0.756^{* * * *} \\
(0.22) \\
\end{array}$ & $\begin{array}{c}-0.718^{*} \\
(0.36) \\
\end{array}$ & $\begin{array}{c}-1.293^{* * * *} \\
(0.21) \\
\end{array}$ \\
\hline $\begin{array}{l}\text { Random effect } \\
\text { SD constant }\end{array}$ & 0.171 & 0.090 & 0.268 & 0.228 & 0.292 \\
\hline $\begin{array}{l}\text { Log likelihood } \\
\text { BIC }\end{array}$ & $\begin{array}{c}-42,263.315 \\
84,600.2\end{array}$ & $\begin{array}{c}-26,708.095 \\
53,467.4\end{array}$ & $\begin{array}{c}-39,700.686 \\
79,473.9\end{array}$ & $\begin{array}{c}-24,880.075 \\
49,790.0\end{array}$ & $\begin{array}{c}-71,343.697 \\
142,818.0\end{array}$ \\
\hline
\end{tabular}


Table A2 Descriptive statistics of research and control variables by welfare-state regime (WSR) type.

\begin{tabular}{|c|c|c|c|c|c|c|}
\hline Variable & Operationalization & $\begin{array}{c}\text { Conservative } \\
\text { WSR }\end{array}$ & $\begin{array}{c}\text { Social- } \\
\text { democratic } \\
\text { WSR }\end{array}$ & $\begin{array}{l}\text { Family- } \\
\text { oriented } \\
\text { WSR }\end{array}$ & Liberal WSR & $\begin{array}{c}\text { Post-socialist } \\
\text { WSR }\end{array}$ \\
\hline $\begin{array}{l}\text { Subjective } \\
\text { Well-Being }\end{array}$ & $\begin{array}{l}\text { Two-item scale } \\
\text { reflecting affectual } \\
\text { and cognitive } \\
\text { dimension of SWB: } \\
\text { happiness and life } \\
\text { satisfaction }\end{array}$ & $\begin{array}{l}\text { Mean (SD) } \\
7.16(1.83)\end{array}$ & $\begin{array}{l}\text { Mean (SD) } \\
8.04(1.42)\end{array}$ & $\begin{array}{l}\text { Mean (SD) } \\
6.72(2.04)\end{array}$ & $\begin{array}{l}\text { Mean (SD) } \\
7.29(1.84)\end{array}$ & $\begin{array}{l}\text { Mean (SD) } \\
5.76(2.18)\end{array}$ \\
\hline Status & $\begin{array}{c}\text { International Socio- } \\
\text { Economic Index } \\
\text { (ISEI) }\end{array}$ & $\begin{array}{c}\text { Mean(SD) } \\
\text { 45.82(17.21) }\end{array}$ & $\begin{array}{c}\text { Mean(SD) } \\
45.38(18.21)\end{array}$ & $\begin{array}{c}\text { Mean(SD) } \\
39.76(17.48)\end{array}$ & $\begin{array}{c}\text { Mean(SD) } \\
43.78(17.74)\end{array}$ & $\begin{array}{c}\text { Mean(SD) } \\
41.60(17.86)\end{array}$ \\
\hline GDP & $\begin{array}{c}\text { Logged GDP per } \\
\text { capita, by country, } \\
\text { and period } \\
\end{array}$ & $\begin{array}{l}\text { Mean(SD) } \\
10.52(0.06)\end{array}$ & $\begin{array}{c}\text { Mean(SD) } \\
10.81(0.21)\end{array}$ & $\begin{array}{l}\text { Mean(SD) } \\
10.02(0.44)\end{array}$ & $\begin{array}{c}\text { Mean(SD) } \\
10.46(0.33)\end{array}$ & $\begin{array}{l}\text { Mean(SD) } \\
9.14(0.66)\end{array}$ \\
\hline Gini & $\begin{array}{l}\text { Gini coefficient of } \\
\text { equivalized } \\
\text { disposable income } \\
\text { before social } \\
\text { transfers by country } \\
\text { and period } \\
\text { (pensions excluded } \\
\text { from social } \\
\text { transfers, i.e., they } \\
\text { are included in this } \\
\text { Gini measure) }\end{array}$ & $\begin{array}{c}\text { Mean(SD) } \\
35.10(1.30)\end{array}$ & $\begin{array}{c}\text { Mean(SD) } \\
34.44(2.23)\end{array}$ & $\begin{array}{c}\text { Mean(SD) } \\
36.26(2.91)\end{array}$ & $\begin{array}{l}\text { Mean(SD) } \\
39.31(3.95)\end{array}$ & $\begin{array}{l}\text { Mean(SD) } \\
35.42(2.61)\end{array}$ \\
\hline $\begin{array}{l}\text { Educational } \\
\text { level }\end{array}$ & $\begin{array}{c}\text { Proportion of } \\
\text { people with at least } \\
\text { ISCED level 3a } \\
\text { (upper secondary } \\
\text { degree, high) and } \\
\text { above }\end{array}$ & $\begin{array}{c}\text { ISCED level } \\
\text { 3a and above } \\
=43.68 \% \\
\text { ISCED level } \\
\text { below 3a = } \\
56.32 \%\end{array}$ & $\begin{array}{c}\text { ISCED level } \\
\text { 3a and above } \\
=61.37 \% \\
\text { ISCED level } \\
\text { below 3a = } \\
38.63 \%\end{array}$ & $\begin{array}{c}\text { ISCED level } \\
\text { 3a and above } \\
=34.85 \% \\
\text { ISCED level } \\
\text { below 3a = } \\
65.15 \%\end{array}$ & $\begin{array}{c}\text { ISCED level } \\
\text { 3a and above } \\
=45.74 \% \\
\text { ISCED level } \\
\text { below } 3 \mathrm{a}= \\
44.26 \%\end{array}$ & $\begin{array}{c}\text { ISCED level } \\
\text { 3a and above } \\
=68.77 \% \\
\text { ISCED level } \\
\text { below 3a = } \\
31.23 \%\end{array}$ \\
\hline Age & Age in years & $\begin{array}{c}\text { Mean(SD) } \\
50.84(12.19)\end{array}$ & $\begin{array}{c}\text { Mean(SD) } \\
51.21(12.68)\end{array}$ & $\begin{array}{c}\text { Mean(SD) } \\
49.94(12.69)\end{array}$ & $\begin{array}{c}\text { Mean(SD) } \\
50.82(12.39)\end{array}$ & $\begin{array}{c}\text { Mean(SD) } \\
51.41(12.20)\end{array}$ \\
\hline Age, squared & $\begin{array}{l}\text { Age in years, } \\
\text { squared }\end{array}$ & $\begin{array}{c}\text { Mean (SD) } \\
2733.33 \\
(1272.64)\end{array}$ & $\begin{array}{c}\text { Mean (SD) } \\
2783.10 \\
(1311.85)\end{array}$ & $\begin{array}{c}\text { Mean (SD) } \\
2654.96 \\
(1311.22) \\
\end{array}$ & $\begin{array}{c}\text { Mean (SD) } \\
2736.56 \\
(1284.51) \\
\end{array}$ & $\begin{array}{c}\text { Mean (SD) } \\
2792.26 \\
(1286.05) \\
\end{array}$ \\
\hline $\begin{array}{l}\text { Subjective } \\
\text { general health }\end{array}$ & $\begin{array}{c}\text { (1 very bad, } 5 \text { very } \\
\text { good) }\end{array}$ & $\begin{array}{l}\text { Mean(SD) } \\
3.73(0.85)\end{array}$ & $\begin{array}{l}\text { Mean(SD) } \\
3.98(0.87)\end{array}$ & $\begin{array}{l}\text { Mean(SD) } \\
3.65(0.86)\end{array}$ & $\begin{array}{l}\text { Mean(SD) } \\
3.90(0.92)\end{array}$ & $\begin{array}{l}\text { Mean(SD) } \\
3.21(0.82)\end{array}$ \\
\hline Unemployed & $\begin{array}{c}\text { Unemployed, } \\
\text { looking actively for } \\
\text { job (last } 7 \text { days) vs } \\
\text { all other }\end{array}$ & $3.13 \%$ & $2.61 \%$ & $5.77 \%$ & $2.66 \%$ & $4.33 \%$ \\
\hline Female & Self-reported sex & $51.59 \%$ & $49.34 \%$ & $52.90 \%$ & $53.05 \%$ & $57.75 \%$ \\
\hline
\end{tabular}

$a$. Weighted (population size weight, design weight). For conservative, social-democratic, family-oriented, liberal, and post-socialist WSR $n$ ranges between 25,009 and 38,628, 23,562 and 28,784, 29,039 and 37,595, 12,837 and 22,110, and 33,554 and 57,105, respectively. 


\section{Bibliography}

Aidukaite, J. (2004). The emergence of the post-socialist welfare state: the case of the Baltic states: Estonia, Latvia and Lithuania. Huddinge: Södertörns Högskola.

Alesina, A., Di Tella, R., \& MacCulloch, R. (2004). Inequality and happiness. Are Europeans and Americans different? Journal of Public Economics, 88, 2009-2042.

Arts, W., \& Gelissen, J. (2002). Three Worlds of Welfare Capitalism or More? A State-of-the-Art Report. Journal of European Social Policy, 12, 137-158.

Arts, W., \& Gelissen, J. (2010). Models of the Welfare State. In F. G. Castles, S. Leibfried, J. Lewis, H. Obinger, \& C. Pierson (Eds.), The Oxford Handbook of the Welfare State (pp. 569-583), Oxford: Oxford University Press.

de Beer, P., Vrooman, C., \& Wildboer Schut, J. M. (2001). Measuring welfare state performance: three or two worlds of welfare capitalism? Luxembourg: LIS.

Berg, M. C., \& Veenhoven, R. (2010). Income inequality and happiness in 119 nations: in search for an optimum that does not appear to exist. In B. Greve (Ed.), Social policy, happiness in Europe (pp. 174-194). Cheltenham: Edward Elgar.

Berger, J., Zelditch, M., Andersen, B., \& Cohen, B. P. (1972). Structural aspects of distributive justice. In J. Berger, M. Zelditch \& B. Andersen (Eds.), Sociological theories in progress (pp. 119-246). New York: Houghton Mifflin.

Böhnke, P. (2008). Does society matter? Life satisfaction in the enlarged Europe. Social Indicators Research, 87, 189-210.

Bonini, A. N. (2008). Cross-national variation in individual life satisfaction: Effects of national wealth, human development, and environmental conditions. Social Indicators Research, 87, 223-236.

Bonoli, G. (1997). Classifying welfare states: a two-dimension approach. Journal of Social Policy, 26, 351-372. 
Breen, R., \& Goldthorpe, J. H. (1997). Explaining educational differentials: towards a formal rational action theory. Rationality and Society, 9, 275-305.

Castles, F. G., \& Mitchell, D. (1990). Three worlds of welfare capitalism or four? Canberra.

Deacon, B. (1993). Developments in East European social policy. In C. Jones (Ed.), New perspective on the welfare state in Europe (pp. 177-198). London: Routledge.

Delhey, J., \& Kohler, U. (2011). Is happiness inequality immune to income inequality? New evidence through instrument-effect-corrected standard deviations. Social Science Research, 40, 742-756.

Diener, E. (1994). Assessing subjective well-being: progress and opportunities. Social Indicators Research, 31, 103-157.

Diener, E. (2009). The science of well-being: the collected works of Ed Diener. New York: Springer.

Diener, E., \& Lucas, R. (2000). Explaining differences in societal levels of happiness: Relative standards, need fulfillment, culture, and evaluation theory. Journal of Happiness Studies, 1, 41-78.

Diener, E., \& Suh, E. M. (1997). Measuring quality of life: economic, social, and subjective indicators. Social Indicators Research, 40, 189-216.

Diener, E., Suh, E. M., Lucas, R., \& Smith, H. L. (1999). Subjective well-being: three decades of progress. Psychological Bulletin, 125, 276-302.

Di Tella, R., MacCulloch R. J., \& Oswald A. J. (2001). Preferences over Inflation and Unemployment. Evidence from Surveys of Happiness. American Economic Review, 91, 335-341.

Di Tella, R., MacCulloch R. J., \& Oswald A. J. (2003). The macroeconomics of happiness. The Review of Economics and Statistics, 85, 809-827.

Ebbinghaus, B. (2011). Case Selection in Medium-N Comparative Welfare State Analysis. Qualitative \& Multi-Method Research, APSA Section Newsletter, 2011/Fall, 15-20. 
Ervasti, H., \& Venetoklis, T. (2010). Unemployment and Subjective Well-being. Acta Sociologica, 53:119-139.

Esping-Andersen, G. (1990). The three worlds of welfare capitalism. Cambridge: Polity Press. Esping-Andersen, G. (1999). Social foundations of postindustrial economies. Oxford: Oxford University Press.

Eurostat (2015). Statistical office of the European Union. Retrieved March 8, 2015 from http://appsso.eurostat.ec.europa.eu/nui/show.do?dataset=ilc_di12c\&lang=en .

Ferrera, M. (1996). The southern model of welfare in social Europe. Journal of European Social Policy, 6, 17-37.

Festinger, L. (1954). A theory of social comparison processes. Human Relations, 7, 117-140.

Frey, B. S., \& Stutzer, A. (2002). What can economists learn from happiness research? Journal of Economic Literature, 40, 402-435.

Frey, B. S. \& Stutzer, A. (2005). Happiness research: state and prospects. Review of Social Economy, 63, 207-228.

Ganzeboom, H. B. G., \& Treiman, D. J. (1996). Internationally comparable measures of occupational status for the 1988 international standard classification of occupations. Social Science Research, 25, 201-239.

Hadjar, A., \& Backes, S. (2013). Migration background and subjective well-being a multilevel analysis based on the European social survey. Comparative Sociology, 12, 645676.

Hadjar, A., Haunberger, S., \& Schubert, F. (2008). Bildung und subjektives Wohlbefinden im Zeitverlauf, 1984-2002. Eine Mehrebenenanalyse. Berliner Journal für Soziologie, 18, 370-400.

Hadjar, A., \& Samuel, R. (2015). Does upward social mobility increase life satisfaction? A longitudinal analysis using British and Swiss panel data', Research in Social Stratification and Mobility, 39, 48-58. 
Hanssen, M. (2011). Is equality a determinant of well-being? A cross-national analysis of income inequality and self-reported life satisfaction. Master's Thesis, Department of Public Policy. Washington, D.C.: Georgetown University.

Hega, G. M., \& Hokenmaier K. G. (2002). The welfare state and education. A comparison of social and educational policy in advanced industrial societies. German Political Studies, 2, $143-173$.

Hirsch, F. (1977). The social limits to growth. London: Routledge \& Kegan Paul.

Hyman, H. H., \& Singer, E. (1968). Readings in reference group theory and research. New York: Free Press.

Inglehart, R., \& Klingemann, H.D. (2000). Genes, culture, democracy, and happiness. In E. Diener (Ed.), Culture and subjective well-being (pp. 165-184). Cambridge: MIT Press.

Kelley, J., \& Evans, M. D. R. (2012). Societal inequality and individual subjective well-being: Results from 96 societies and 300,000 individuals, 1981-2008. Annual Meeting of the American Sociological Association, Denver.

Korpi, W., \& Palme, J. (1998). The paradox of redistribution and strategies of equality: Welfare state institutions, inequality, and poverty in the western countries. American Sociological Review, 63, 661-687.

Marx, K. (1968 [1847]). Wage labour and capital. In K. Marx \& F. Engels, Selected works (pp. 74-97). New York: International Publishers.

Merton, R. K., \& Kitt, A. S. (1950). Contributions to the theory of reference group behavior. In R. K. Merton, \& P. F. Lazarsfeld (Eds.), Continuities in social research: Studies in the scope, method of the American soldier (pp. 40-105). Glencoe, IL: Free Press.

Noll, H. H., \& Weick, S. (2012). Nicht einmal jeder Dritte empfindet soziale Unterschiede in Deutschland als gerecht: Analysen zur Entwicklung von Einstellungen zur sozialen Ungleichheit in Deutschland. In: Informationsdienst Soziale Indikatoren 48, pp. 6-11. Retrived from http://nbn-resolving.de/urn:nbn:de:0168-ssoar-314445 
Ormel, J., Lindenberg, S., Steverink, N., \& Verbrugge, L. M. (1999). Subjective well-being and social production functions. Social Indicators Research, 46, 61-90.

Pedersen, P.J., \& Schmidt, T. D. (2009). Happiness in Europe : cross-country differences in the determinants of subjective well-being. IZA Discussion Paper Series No. 4538.

Samuel, R., Bergman, M. M., \& Hupka-Brunner, S. (2013). The interplay between educational achievement, occupational success, and well-being. Social Indicators Research, 111, 75-96.

Schmid, J. (2002). Wohlfahrtsstaaten im Vergleich. Soziale Sicherung in Europa:

Organisation, Finanzierung, Leistungen und Probleme. Opladen: Leske + Budrich Verlag.

Schubert, K., Hegelich, S., \& Bazant, U. (2008). Europäische Wohlfahrtssysteme. Ein Handbuch. Wiesbaden: VS Verlag für Sozialwissenschaften.

Scruggs, L., \& Allan, J. (2006). Welfare-state decommodification in 18 OECD countries. A replication and revision. Journal of European Social Policy, 16, 55-72.

Snowdon, C. (2010). The spirit level delusion: Fact-checking the left's new theory of everything. London: Little Dice.

Stiglitz, J. E. (2012). The price of inequality: How today's divided society endangers our future. New York: W.W. Norton \& Company.

Stocké, V. (2007). Explaining educational decision and effects of families’ social class position: An empirical test of the Breen-Goldthorpe model of educational attainment. European Sociological Review, 23, 505-519.

Terwey, M. (1990). Zur Wahrnehmung von wirtschaftlichen Lagen in der Bundesrepublik. In W. Müller, P. Ph. Mohler \& B. Erbslöh/Martina Wasmer (Eds.), Blickpunkt Gesellschaft. Einstellungen und Verhalten der Bundesbürger (pp. 144-190). Opladen: Westdeutscher Verlag.

Thomas, W. I., \& Thomas, D. S. (1928). The child in America. Behavior problems and programs. New York: Knopf. 
Trampusch, C. (2010). The welfare state and trade unions in Switzerland: an historical reconstruction of the shift from a liberal to a post-liberal welfare regime. Journal of European Social Policy, 20, 58-73.

Treiman, D. J. (1970). Industrialization and Social Stratification. Sociological Inquiry, 40, 207-234.

Veenhoven, R. (2001). Happiness in society. In J. Allmendinger (Ed.), Gute Gesellschaft?: Verhandlungen des 30. Kongresses der Deutschen Gesellschaft für Soziologie in Köln 2000. Opladen: Leske + Budrich Verlag.

Veenhoven, R. (2000). Well-Being in the welfare state: Level not higher, distribution not more equitable. Journal of Comparative Policy Analysis, 2, 91-125.

Veenhoven, R. (2005). Return of inequality in modern society? Test by dispersion of life satisfaction across time and space. Journal of Happiness Studies, 6, 457-487.

Verbakel, E. (2013). Leisure values of Europeans from 46 Countries. European Sociological Review, 29, 669-682.

Wilkinson, R. G., \& Pickett, K. E. (2010). The spirit level: Why equality is better for everyone. London: Penguin Books.

Winkelmann, L., \& Winkelmann, R. (1998.: Why are unemployed so unhappy? Evidence from panel data. Economica, 65, 1-15.

World Bank (2015). GDP per capita. World Bank national accounts data, and OECD National Accounts data files. Retrieved March 17, 2015. (http://data.worldbank.org/indicator/NY.GDP.PCAP.CD?page=2).

Zagorski, K., Evans, M. D. R, Kelley. J., \& and Piotrowska, K. (2014). Does national income inequality affect individual's quality of life in Europe? Inequality, happiness, finances and health. Social Indicators Research, 117, 1089-1110. 